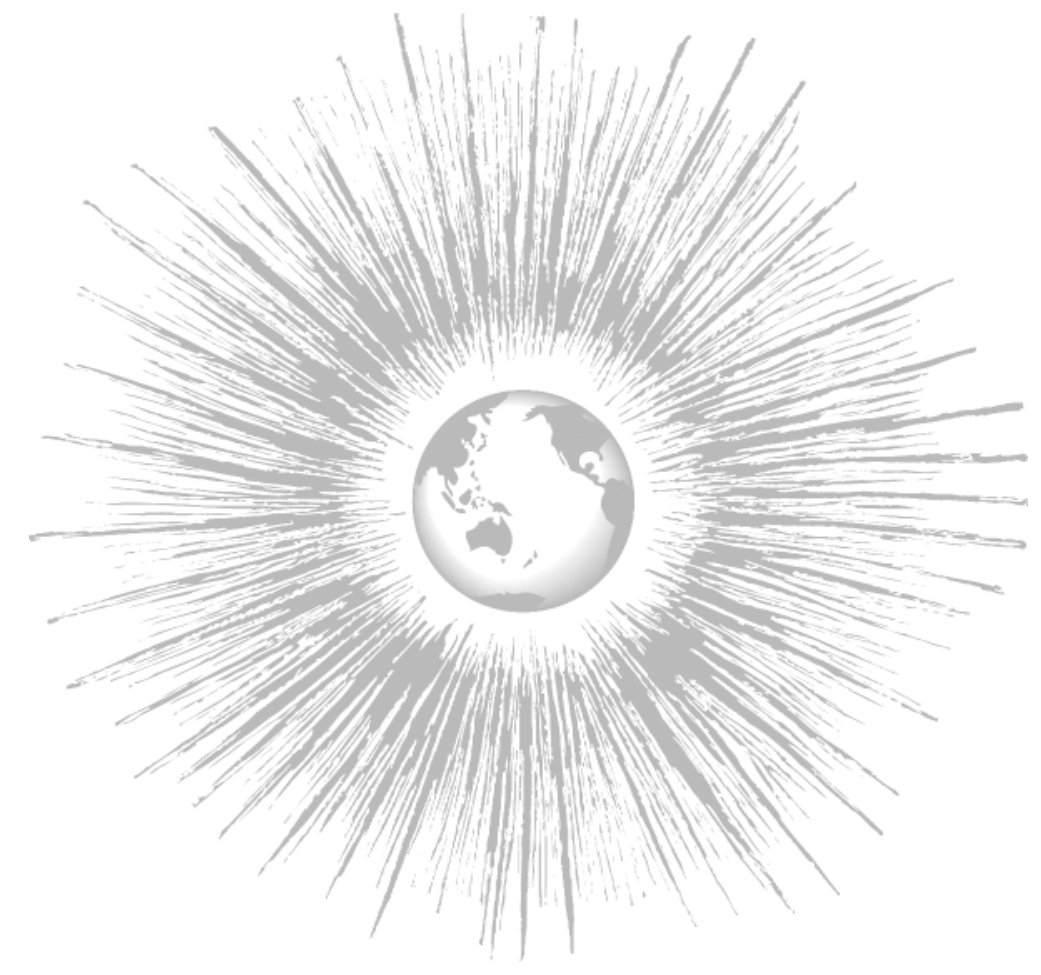

ABSTRACT:

In a recent synopsis of theories and findings on transnational corporate ties published in this journal, Nollert (2005) argues that while there may be good theoretical reasons to hypothesize the emergence of a Transnationa Capitalist Class (TCC), to this point there is relatively little empirical evidence, aside from Sklair's (200I) work, to support the claim that such a class exists or is forming. However, a few researchers have attempted to apply the study of interlocking directorates to the search for a network of transnational direc tors who might be in a position to form such a class. Drawing on empirical findings on the world's largest transnational corporation and banks reported elsewhere (Staples 2007a; Staples 2007b), as well as additional analyse done specifically for this paper, I argue that studies that rely exclusively on transnationa corporate interlocks dramatically underestimate the extent of the TCC network because TCC to emerge.

\section{Board Interlocks and the Study of the Transnational Capitalist Class ${ }^{*}$}

Clifford L. Staples

\section{INTRODUCTION}

Tn a recent synopsis of theories and findings on transnational corporate ties 1 published in this journal, Nollert (2005) argues that while there may be good theoretical reasons to predict the emergence of a Transnational Capitalist Class (TCC), at present there is not much evidence to support the claim that such a class exists or is forming. Since relatively few empirical studies of the TCC are available (Sklair 200I; Carroll and Fennema 2002; Carroll and Carson 2003; Carroll and Fennema 2004; Kentor and Jang 2004; Kentor and Jang 2006; Carroll and Fennema 2006; Nollert 2005), the absence of convincing evidence for the existence of a TCC is not surprising, but if work on this interesting and important topic is to advance, we do need more empirical studies on the TCC from a variety of theoretical and methodological perspectives. Building on previous work (Staples 2007a; Staples 2007b), the purpose of this paper is to advance the sociological study of the TCC by offering an appreciative, empirically grounded, critique of the prevailing interlocking directorate approach to this problem (Carroll and Fennema 2002; Carroll and Fennema 2004; Kentor and Jang 2004; Kentor and Jang 2006; Carroll and Fennema 2006). While these researchers disagree over sampling issues, the interpretation of findings, and other matters, they would seem to agree that evidence of a TCC, or at least a TCC "in-itself," is to be found primarily in the presence of corporate interlocks within the global economy, particularly "transnational interlocks" in which a director

tions between corporations and miss transnational connections within corporations-connections that have grown more numerous in recent years as corporate boards have become more multinational, largely as a result of the concentration of global capital. Counting both between and within transnational capitalist connections points to a far greater level of capitalist transnationality than is suggested by focusing exclusively on between corporate connections, as has been done in this work so far. And while the existence of such a network falls well short of convincing proof that a TCC exists, it does show that capitalists from different countries increasingly have opportunities to interact as they work together to run the world's largest corporations, and it is out of such interactions that we would expect a

\section{Clifford L. Staples \\ Department of Sociology \\ University of North Dakota \\ Gillette Hall Room 202 \\ 225 Centennial Drive Stop 7136 \\ Grand Forks, ND 58202-7136 \\ clifford staples@und.nodak.edu \\ http://www.und.edu/dept/soc/}

* My thanks to Bill Domhoff, Kathleen Tiemann, and a JWSR reviewer for comments on an earlier version of this paper.

JOURNAL OF WORLD-SYSTEMS RESEARCH, XII, 2, DECEMBER 2006, 309-3I9

http://www.jwsr.org

ISSN $1076-156 \mathrm{X}$

(C) 2006 Clifford L. Staples 
serves on the board of two (or more) corporations from different countries. As is discussed below, I have no particular quarrel with studying transnational corporate interlocks as a first step in the search for evidence of a TCC, but what I try to show using data on the I48 largest transnational corporations and banks (TNCS), is that an exclusive focus on the transnational connections between capitalists from different corporations (i.e. corporate interlocks) would appear to rather dramatically underestimate the extent of transnational connectedness among the directors of the world's largest corporations. This problem occurs because these researchers have so far failed to register the increasingly important transnational ties that exist between directors from different nations who serve on the same TNC boards. In short, researchers so far have counted only transnational links between corporations and have ignored the transnational links that now increasingly occur within corporations. These links have come about as a result of what I have called "board globalization,"- a phenomenon driven in large part by the dramatic upsurge in cross-border acquisitions in the late 1990s (Staples 2007a; Staples 2007b).

Nollert (2005) has recently provided a thoughtful overview of research on transnational corporate ties, and so I will not recycle that discussion here. And elsewhere (Staples 2007b) I have explained my particular approach to the study of the TCC. My specific purpose here is to inform researchers that the increasingly multinational composition of TNC boards means that transnational capitalist networks exist within as well as between transnational corporations, and to argue that we must pay attention to these within-corporation networks as well as between corporation networks as we try to map and monitor the hypothesized emergence of the TCC.

In part one I offer a definition of the TCC to help assess empirical studies designed to study it. In part two I show, using data collected on the world's largest TNCS and their directors for 2005 , how an exclusive focus on connections between corporations dramatically underestimates the extent of connections that exist between capitalists from different nations. And while the existence of such a network falls well short of convincing proof that a TCC exists, it does show that capitalists from different countries increasingly have opportunities to interact as they work together to run the world's largest corporations, and it is out of such interactions that we would expect a TCC to emerge.

\section{THE TRANSNATIONAL CAPITALIST CLASS}

Capitalist class formation is conceived here as a process in which individuals who share a common position relative to the appropriation of profit (via capitalist production) evolve into a self-conscious, socially-exclusive elite who recognize that they share common interests in preserving capitalism and their position within it and are prepared to act to preserve those interests (Marx 1976 [I867]; Resnick and Wolff 1987:109-63; Robinson 2004:36). Marx attempted to capture the beginning and end of this class formation process, of course, with his famous concepts of a "class-in-itself" and a "class-for-itself" (Marx 1995 [I847]:I88-89). As a rough approximation, these terms, and the socio-historical process they imply, are useful. But the process itself must be studied closely and empirically, as Marx himself did, in any particular time and place. As I envision it, then, to study the process of capitalist class formation, means first identifying the people who are in a position to appropriate the fruits of capitalist production. Once we identify who the capitalists are, we can then chart their social arrangements and networks in order to monitor their evolution from a "class-in-itself" to a "class-for-itself."

To date, perhaps owing to at least a tacit acceptance of a basic Marxist understanding of capitalism and class, most researchers who study the TCC seem to be working implicitly with something like the above definition (Sklair 200I:I7; Robinson 2004:36; Carroll and Fennema 2002:396; Kentor and Jang 2004:357). Moreover, when it comes to actually doing empirical work, everyone involved agrees that the directors and executives of transnational corporations are the most important, if not the only, members of any TCC. This is, of course, why most of the researchers working on this topic have focused on mapping the network of interlocking directorates: the presumption is that the existence of such a network is a prerequisite to TCC formation. As Nollert recently put it when discussing the existing evidence on the TCC, "...until we can identify a social network whose members share a transnational identity and pursue common political interests, we cannot verify the existence of a transnational class" (Nollert 2005:294). All researchers working on this problem would seem to agree with Nollert that identifying this transnational social network is a necessary, though insufficient, first step in the study of the TCC.

Thus, most empirical work on the TCC has focused on the problem of identifying the social network of transnational capitalists from whom we would at some point presumably expect to see emerge a transnational identity and the pursuit of common political interests. ${ }^{1}$ To this point, two teams of researchers-Carroll and Fennema on the one hand, and Kentor and Jang on the other

1. As a reviewer of this paper pointed out, in agreement with Nollert, network analysis alone does not demonstrate the existence of a TCC. I couldn't agree more, which is why I see this work as but the first step in the search for such evidence. First we have to identify the individuals involved; then we can figure out what they are doing, and whether those doings looks like the doings of a Transnational Capitalist Class. 
hand, have produced conflicting findings on the extent of growth over the past thirty years in the global network of corporate directors, and have been trying to reconcile those findings while arguing about methodological issues (Carroll and Fennema 2002; Carroll and Fennema 2004; Kentor and Jang 2004; Kentor and Jang 2006; Carroll and Fennema 2006; Nollert 2005). I am less concerned, however, with what these researchers disagree about than with what they seem to agree upon: that the existence of the transnational social network is to be found in the linkages that occur between corporations from different countries as a result of director interlocks. As I will try to show below, I think the exclusive focus on connections between directors from different corporations underestimates the extent of the transnational capitalist social network.

To understand the problem it is necessary to consider just what it is we think is "transnational" about the Transnational Capitalist Class. Research on this topic has grown out of a tradition of research going back at least to Mills' work in the 1950s and Domhoff's work beginning in the r96os (Mills 1956; Domhoff 2006; see also Zeitlin 1989) on national capitalist classes, and in this literature it was always assumed that the national capitalist classes consisted largely of citizens of the nation in question. Against this background of the study of a national capitalist class, what has captivated the interest of observers in and out (Faux 2006) of academia is how the globalization of capitalist production might today be generating a class of individuals who develop identities that override, displace, or subordinate their national identities.

Sklair (200I:2) notes that “...transnational refers to forces, processes, and institutions that cross borders but do not derive their power and authority from the state." Given this definition, and the sociological commonplace that social identities emerge from social interaction, the emergence of transnational capitalist class identities is predicated on the existence of a transnational network of individual capitalists. In short, a member of the transnational capitalist class is presumed to develop feelings of commonality and shared interests with capitalists from other nations. ${ }^{2}$ The Transnational Capitalist Class is, therefore, also a multinational capitalist class. And looking for evidence of a multinational capitalist class is just what Carroll, Fennema, Kentor, and Jang would appear to be doing when they identify transnational corporate interlocks, i.e. directors who serve on the boards of corporations from different countries.

2. While it is possible to imagine a supra-national capitalist class consisting of individuals from one nation-all of the world's largest transnational firms owned and run by U.S. nationals, for example-it might be more appropriate to refer to such a class as an Imperialist Capitalist Class rather than a Transnational Capitalist Class.

\section{TRANSNATIONAL LINKAGES BETWEEN AND WITHIN CORPORATIONS}

For my purposes, the most important evidence produced by the work of Carroll, Fennema, Kentor, and Jang concerns the number of transnational lines (links or connections) identified in the network of interlocking directorates that make up the global corporate economy. In their 2002 article entitled "Is There a Transnational Business Community?" Carroll and Fennema (2002: 408) write: "...the entire international network consists in a combination of national lines (interlocks between companies headquartered in the same country) and transnational lines (interlocks between companies headquartered in different countries)." These researchers then go on to report, based on a much earlier groundbreaking study by Fennema (1982), that the number of such transnational links was 84 in 1976 and 88 in 1996, and that this change represented only a very small increase in the proportion of transnational to total links from $22.8 \%$ to $24.8 \%$. From this they conclude that there has not been much growth in the transnationality of the world's national capitalist classes during this twenty year period.

In a critique of this work published in 2004 entitled "Yes, There is a (Growing) Transnational Business Community" Kentor and Jang (2004) take issue with Carroll and Fennema's sampling, and provide evidence from a study of the Fortune Global 500 of 120 transnational links in 1983 and 186 transnational links in 1998 , but with lower proportions of transnational links- $13.2 \%$ in 1983 and $17.0 \%$ in 1998 than were reported by Carroll and Fennema (Kentor and Jang 2004:359). And while these researchers continue to argue over theoretical and methodological issues (Carroll and Fennema 2004; Kentor and Jang 2006; Carroll and Fennema 2006), it is critical for the discussion below to understand that (I) both groups of researchers have attempted to measure the growth in the transnational capitalist social network primarily in terms of interlocks between companies headquartered in different countries, and (2) neither group of researchers has so far attempted to directly measure the nationalities of their capitalist directors.

While none of the researchers above explicitly discuss how directors who serve on corporate boards headquartered in different countries function as a transnational capitalist (or "business") network, it seems safe to assume that something like the following underlies their reasoning: corporations headquartered in different countries will be directed by individuals from different countries and so when, for example, a director from a Canadian company also serves on the board of a French company, this interlock brings together that Canadian director with a board of French (or at least predominantly French) directors, producing a cluster of links in what is presumably a wider network of transna- 
Table 1 - Increase in TNC Board Globalization 1993-2005

\begin{tabular}{ccc}
\hline Presence of Non-National Board Member 1993 & $51(63.8 \%)$ & $29(36.2 \%)$ \\
Presence of Non-National Board Member 2005 & $20(25.0 \%)$ & $60(75.0 \%)$
\end{tabular}

tional capitalist directors. This is an entirely reasonable assumption (assuming, as well, that all of the directors involved are not from the same country), and so given that a Transnational Capitalist Class must, by definition, also be a multinational capitalist class, research such as that conducted by Carroll, Fennema, Kentor, and Jang that focuses on transnational interlocks does, I believe, provide us with a measure of the extent to which a TCC-in-itself exists.

At the same time, because these researchers have not to this point attempted to directly measure the nationalities of the directors who we believe should make up the TCC, there is reason to believe that this research rather dramatically underestimates the extent of transnational linkages, i.e. linkages between capitalists from different nations, because the increasingly multinational composition of TNC boards makes director relationships within these corporations, and not just the director relationships between corporations, important to TCC formation.

Very little research has been done on the nationalities of the directors who serve on transnational corporate boards, and so to test the hypothesis that TNC boards are becoming increasingly "globalized," or multinational, I recently designed a study of board globalization among 80 of the world's largest TNC $S$ for the period 1993-2005 (Staples 2007a). This study confirmed that board globalization increased among TNC s during this time. I reported (see Table I) that while in 1993 only $29 / 80$ or $36.3 \%$ of these companies had at least one nonnational board member, by $200560 / 80$ or $75 \%$ of these companies had at least one non-national board member-evidence of a substantial increase in board globalization during the past decade.

At the same time, however, the evidence also showed that while the practice of appointing "foreign" board members had certainly become more widespread among the world's largest TNC S, on average national board members were still in the majority; $25 \%$ of these corporations had no non-national directors; $66 \%$ had $50 \%$ or fewer; and only $9 \%$ had more than $50 \%$. In the aggregate, of the 929 directors running these TNCS in 2005,228 or $24.5 \%$ were "foreigners" on the boards on which they served. Nevertheless, the evidence from this study shows that if we are interested in connections between capitalists from different countries, it is no longer possible to focus exclusively on links between corporations; we must also take account of links between capitalists from different countries that exist within corporations, and to do so we must directly measure the nationalities of directors. ${ }^{3}$

To illustrate the implications of ignoring within-company links between capitalists from different nations, I use data from my on-going research on the world's 148 largest TNC S and banks collected in late 2005 (see the Appendix for the list of TNC S studied). Methodological details for this work can be found in Staples (2006a; 2006b).

First, I computed the number of transnational links a la Carroll \& Fennema (Carroll and Fennema 2002:408) and found that of the 313 lines connecting one corporation to another in my data 105 connected directors who served on the boards of corporations from different countries, i.e. there were I05 transnational corporate interlocks. This is a slightly higher proportion of transnational links-33.5\% - than Carroll and Fennema found for 1996 (24.8\%), and double what was found by Kentor and Jang for 1998 (17.0\%). But, given that I measure individual nationality directly (rather than use the "corporate nationality as a proxy) and that my sample is the smallest, most recent, and also is restricted to the very largest and most highly transnational (in terms of operations) TNC s, the higher level of transnationality is not entirely unexpected. In any case, my point here is not so much to provide new estimates of corporate transnationality as it is to show how any such estimates will be too low if the increasingly multinational composition of TNC boards is not taken into account.

As discussed above, the increase in the frequency of multinational TNC boards that I reported previously (Staples 2007a) means that an exclusive focus on transnational links between corporations misses the transnational links that occur between directors who serve on the same boards. My sample of I48 TNC S includes 2,I47 director positions. To count the number of total and transnational links within corporations I first calculated, for each corporation, the total number of possible unique dyadic links (i.e. unique relationships between

3. It should be noted that both Sklair and Robinson have also pointed to the increasing multinational composition of TNC boards as evidence of TCC formation (Sklair 2001:22, 79; Robinson 2004:62-64); however, these researchers only noted this trend in passing, and relied exclusively on secondary sources. 
any two directors). For these 148 corporations there are a total of 16,183 unique dyadic links possible. ${ }^{4}$ I then calculated that of the total number of possible links, $4,06 \mathrm{I}$, or $25.09 \%$, are transnational links. That is, $4,06 \mathrm{I}$ links connect directors from different countries who serve on the same TNC boards. What these results show, is that if we define the TCC as, at minimum, consisting of a network of capitalists from different countries (Nollert 2005), then it is clear that ignoring the transnational links that exist between capitalists from different countries who serve on the same TNC boards rather dramatically underestimates (in my sample, I05 versus I05+4,06I=4,166) the number of such linkages that exist in the upper echelons of the corporate global economy. Thus, if we want to accurately map and monitor the expected emergence of a TCC from the network of transnational corporate directors, it seems critical in the future to examine both the connections and relationships that are formed within corporate boards as well as those that exist between them. This is not to say that these two different types of linkages have exactly the same consequences for TCC formation, only that both types of linkages are likely relevant for TCC formation. Future empirical research will be necessary to determine if or how they differ.

But, as implied above, for the study of the TCC to move forward it will become increasingly important for researchers to collect data on the nationalities of individual directors-currently no easy task (Staples 2007a; Staples 2007b). Yet, the necessity of doing so-at least for studies specifically designed to explore the emergence of a TCC-is clear. If the Transnational Capitalist Class is thought to consist of capitalists from different nations, i.e. if it is a multinational class, then obviously to identify this class we need data on the nationalities of the individuals who are believed to comprise it. Moreover, there is no reason to believe that the trend toward more multinational boards will stop or reverse-in fact, reading the business press one would conclude that the trend is only likely to continue-and so these boards, acting as thousands of mini "World Economic Forums" will constitute an ever-increasing proportion of transnational capitalist ties. And so studying what is going on within TNC board rooms is going to become increasingly important.

Once we are able to establish the existence of such a multinational network of capitalist directors we can then move on, as Nollert (2005:294) suggests, to the even more challenging problems of studying the transnational capitalist

4. To calculate this number involves, for a board of $n$ members, the number of combinations of $n$ elements taken 2 at a time, usually called " $n$ choose 2." The formula for each board is $n(n-I) / 2$, and 16,183 is the sum of all the possible links for the 148 boards. identities presumably emerging from this network as well as the political projects undertaken on its behalf.

\section{REFERENCES}

Carroll, William K. and Colin Carson. 2003. "The Network of Global Corporations and Elite Policy Groups: A Structure for Transnational Capitalist Class Formation?" Global Networks 3(I):29-57.

Carroll, William K. and Meindert Fennema. 2002. "Is There a Transnational Business Community?” International Sociology I7(3)ः393-419. . 2004. "Problems in the Study of the Transnational Business Community." International Sociology I9(3):369-78. . 2006. "Asking the Right Questions: A Final Word on the Transnational Business Community." International Sociology $2 \mathrm{I}(4): 607-10$.

Domhoff, G. William. 2006. Who Rules America? Power, Politics E Social Change. New York: McGraw-Hill.

Faux, Jeff. 2006. The Global Class War: How America's Bipartisan Elite Lost Our Future - and What It Will Take to Win It Back. Hoboken, N.J: John Wiley \& Sons.

Fennema, Meindert. 1982. International Networks of Banks and Industry. Boston: Martinus Nijhoff.

Kentor, Jeffrey and Yong Suk Jang. 2004. "Yes, There is a (Growing) Transnational Business Community." International Sociology I9(3):355-68. .2006. "Different Questions, Different Answers: A Rejoinder to Carroll and Fennema." International Sociology $2 \mathrm{I}(4): 602-06$.

Marx, Karl. 1976 (1867). Capital, Vol. 1. Harmondsworth: Penguin. . 1995 (1847). The Poverty of Philosophy. New York: Prometheus Books.

Mills, C. Wright. 1956. The Power Elite. New York: Oxford University Press.

Nollert, Michael. 2005. "Transnational Corporate Ties: A Synopsis of Theories and Empirical Findings." Journal of World Systems Research II (2):289-3I4. http://www.jwsr.org

Resnick, Stephen A. and Richard D. Wolff. 1987. Knowledge and Class: A Marxian Critique of Political Economy. Chicago: University of Chicago Press.

Robinson, WIlliam I. 2004. A Theory of Global Capitlaism: Production, Class, and State in a Transnational World. Baltimore: Johns Hopkins University Press.

Robinson, William I. and Jerry Harris. 2000. "Towards a Global Ruling Class? Globalization and the Transnational Capitalist Class." Science E Society 64:1 I-54. Sklair, Leslie. 20or. The Transnational Capitalist Class. Oxford UKः Basil Blackwell.

Staples, Clifford L. 2007a. "Board Globalization in the World's Largest TNC S 1993-2005." Corporate Governance: An International Journal. Forthcoming. . 2007b. "Cross-Border Acquisitions and Board Globalization in the World's Largest TNC S, 1995-2005." The Sociological Quarterly, forthcoming.

Zeitlin, Maurice. 1989. The Large Corporation and Contemporary Classes. New Brunswick, NJ: Rutgers University Press. 
APPENDIX: TRANSNATIONAL CORPORATIONS AND COMMERCIAL

\section{BANKS INCLUDED IN THIS STUDY}

Abbott Laboratores

ABN AMRO

AES

AIG Group

Alcan

Alcoa

Allianz Group

Altria

Anglo American

Aviva

AXA

BAE Systems

Banca Intesa

Bank of America NA

Bank of China

Barclay's Bank

BASF Group

Bayer Group

Bayern

Bertelsmann

BHP Billiton

BMW

BNP Paribas

BP

British American Tobacco

Cadbury Schweppes

Caisse des Depots et Consignations

Carrefour

Chevron

China Construction Bank

Christian Dior

Cie de Saint-Gobain

Citigroup

Commerzbank

ConocoPhillips

Credit Agricole

Credit Suisse

$\mathrm{CRH}$

Daimler-Chrysler

Deutsche Bank

Deutsche Post
Deutsche Telekom

Dexia

Dow Chemical

Du Pont

Duke Energy

DZ Bank Group

E.ON

EDF

Endesa

ENI SPA

ExxonMobil

Fiat

Ford

Fortis

France Telecom

General Electric

General Motors

Glaxosmithkline

Goldman Sachs

Groupe Credit Mutuel

Grupo BBVA

Grupo Santander

Gruppo Assicurazioni Generali

HBOS

Hewlett-Packard

Hitachi

Holcim

Honda Motors

HSBC Bank

Hutchison Whampoa

HVB Group

IBM

Industrial and Commercial Bank of China

ING Group

International Paper

JPMorganChase

Koninklij Ahold

Lafarge

LB-BW

Lloyds TSB Bank

LVMH Moet-Hennessy Louis Vuitton
Marubeni

Matsushita Electric

McDonald's

Merrill Lynch

Metro

Mitsubishi

Mitsubishi Tokyo Financial Group

Mitsui \& Co.

Mizuho Financial Group

Morgan Stanley

Motorola

National Grid Transco

Nestlé

News Corp

Nissan Motor

Nissay

Nokia

Nordea Bank

Norsk Hydro

Novartis

Petronas Gas

Pfizer

Philips Group

Pinault Printemps-Redoute

Procter \& Gamble

Publicis Groupe

Rabobank Nederland

Renault Group

Repsol-YPF

Resona Holdings

Rio Tinto

Robert Bosch

Roche Holding

Royal Bank of Scotland Group

Royal Dutch/Shell Group

RWE Group

Samsung Electronics

Sanofi-Aventis

Scottish Power

Siemens

Singapore Telecommunications

Societe Generale

Sony

Statoil
Stora Enso Oyj

Suez

Sumitomo Mitsui Financial Group

Telecom Italia

Telefonica

Thomson Corporation

Thyssenkrupp

Total

Toyota Motor

UBS

Unilever

United Technologies

Veolia Environment

Verizon

Vivendi Universa

Vodafone Group

Volkswagen

Volvo

Wachovia Bank

Wal-Mart Stores

Wells Fargo Bank

Wyth 